\title{
A Genomics-Based Model for Prediction of Severe Bioprosthetic Mitral Valve Calcification
}

\author{
Anastasia V. Ponasenko ${ }^{1}$, Maria V. Khutornaya ${ }^{1}$, Anton G. Kutikhin ${ }^{1,}$ *, Natalia V. Rutkovskaya ${ }^{1}$, \\ Anna V. Tsepokina ${ }^{1}$, Natalia V. Kondyukova ${ }^{1}$, Arseniy E. Yuzhalin ${ }^{1,2}$ and Leonid S. Barbarash ${ }^{1}$ \\ 1 Research Institute for Complex Issues of Cardiovascular Diseases, Sosnovy Boulvevard 6, \\ Kemerovo 650002, Russia; ponaav@kemcardio.ru (A.V.P.); masha_hut@mail.ru (M.V.K.); \\ rutknv@kemcardio.ru (N.V.R.); annacepokina@mail.ru (A.V.T.); kondnv@kemcardio.ru (N.V.K.); \\ arseniy.yuzhalin@oncology.ox.ac.uk (A.E.Y.); reception@kemcardio.ru (L.S.B.) \\ 2 Department of Oncology, Cancer Research UK and Medical Research Council Oxford Institute for \\ Radiation Oncology, University of Oxford, Old Road Campus Research Building, Roosevelt Drive, \\ Oxford OX3 7DQ, UK \\ * Correspondence: antonkutikhin@gmail.com; Tel.: +7-960-907-70-67
}

Academic Editor: Emil Alexov

Received: 23 June 2016; Accepted: 19 August 2016; Published: 31 August 2016

\begin{abstract}
Severe bioprosthetic mitral valve calcification is a significant problem in cardiovascular surgery. Unfortunately, clinical markers did not demonstrate efficacy in prediction of severe bioprosthetic mitral valve calcification. Here, we examined whether a genomics-based approach is efficient in predicting the risk of severe bioprosthetic mitral valve calcification. A total of 124 consecutive Russian patients who underwent mitral valve replacement surgery were recruited. We investigated the associations of the inherited variation in innate immunity, lipid metabolism and calcium metabolism genes with severe bioprosthetic mitral valve calcification. Genotyping was conducted utilizing the TaqMan assay. Eight gene polymorphisms were significantly associated with severe bioprosthetic mitral valve calcification and were therefore included into stepwise logistic regression which identified male gender, the T/T genotype of the rs 3775073 polymorphism within the TLR6 gene, the C/T genotype of the rs2229238 polymorphism within the IL6R gene, and the A/A genotype of the rs10455872 polymorphism within the LPA gene as independent predictors of severe bioprosthetic mitral valve calcification. The developed genomics-based model had fair predictive value with area under the receiver operating characteristic (ROC) curve of 0.73. In conclusion, our genomics-based approach is efficient for the prediction of severe bioprosthetic mitral valve calcification.
\end{abstract}

Keywords: bioprosthetic heart valve; calcification; interleukin-6; genetic association; predictive model

\section{Introduction}

Mitral valve calcification, accompanied by inflammation and lipid deposition, is associated with common cardiovascular risk factors and represents an important risk factor of mitral valve disease [1,2]. Currently, there is no efficient approach for the prevention of mitral valve disease progression, with valve replacement being the only treatment option [1]. However, bioprosthetic mitral valves also frequently undergo severe calcification which is able to cause bioprosthetic valve failure and may require repeated valve replacement surgery, a major clinical intervention [1]. Even the widely established Carpentier-Edwards Perimount and Medtronic Mosaic bioprosthetic mitral valves undergo severe calcification in up to $20 \%$ of patients $<60$ years $[3,4]$.

Unfortunately, there is still no clinical model for the prediction of severe bioprosthetic mitral valve calcification. A previous study by our research group did not reveal any significant clinical predictors of 
this condition [5]. Mitral valve calcification is frequent among family members [6] but genomic markers of native and bioprosthetic mitral valve calcification are still almost unknown [7]. Nevertheless, their identification may assist in revealing the underlying mechanisms of these conditions. This, in turn, may improve treatment of mitral valve disease.

Progress in genotyping technologies resulted in many studies on the association of single nucleotide polymorphisms (SNPs) with human diseases [8]. SNPs can lead to a number of consequences depending on their location in the genome [9]. As known, SNPs within the noncoding regions are able to affect mRNA splicing or even transcription initiation, while SNPs within the coding regions may alter protein folding, stability, and expression, or influence posttranslational modifications [9]. Here, we investigated whether SNPs within innate immunity, lipid metabolism and calcium metabolism genes are significant predictors of severe bioprosthetic mitral valve calcification.

\section{Results}

We identified eight SNPs being significantly associated with severe bioprosthetic mitral valve calcification (Table 1).

Table 1. Association of the polymorphisms within innate immunity genes, genes of lipid metabolism, and genes of calcium metabolism with severe bioprosthetic mitral valve calcification.

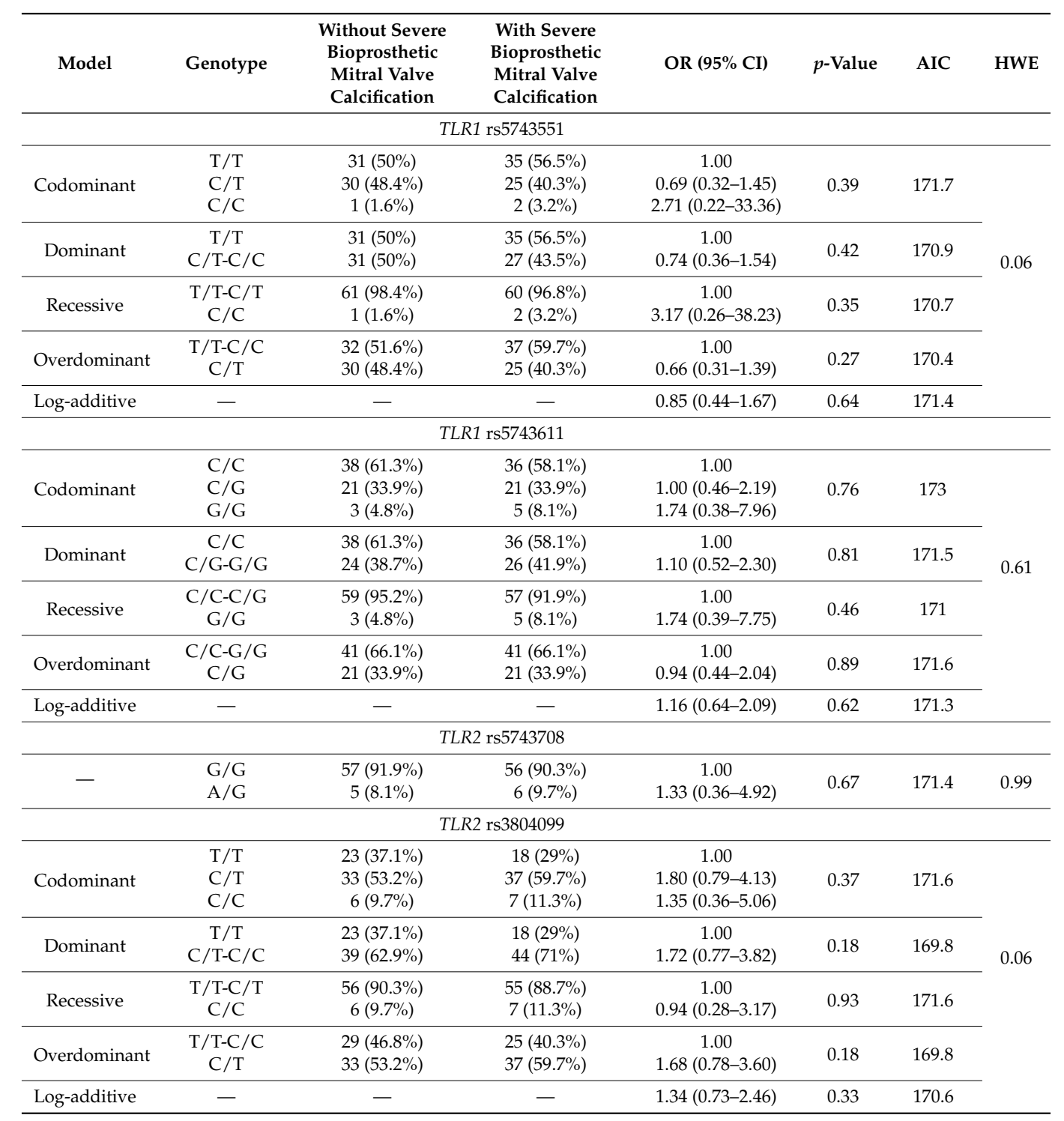


Table 1. Cont.

\begin{tabular}{|c|c|c|c|c|c|c|c|}
\hline Model & Genotype & $\begin{array}{l}\text { Without Severe } \\
\text { Bioprosthetic } \\
\text { Mitral Valve } \\
\text { Calcification }\end{array}$ & $\begin{array}{l}\text { With Severe } \\
\text { Bioprosthetic } \\
\text { Mitral Valve } \\
\text { Calcification }\end{array}$ & OR $(95 \% \mathrm{CI})$ & $p$-Value & AIC & HWE \\
\hline \multicolumn{7}{|c|}{ TLR4 rs4986790 } & \\
\hline \multirow{3}{*}{ Codominant } & $\mathrm{A} / \mathrm{A}$ & $53(85.5 \%)$ & $53(85.5 \%)$ & 1.00 & \multirow{3}{*}{0.46} & \multirow{3}{*}{172} & \multirow{10}{*}{0.53} \\
\hline & $\mathrm{A} / \mathrm{G}$ & $8(12.9 \%)$ & $9(14.5 \%)$ & $1.19(0.41-3.45)$ & & & \\
\hline & $\mathrm{G} / \mathrm{G}$ & $1(1.6 \%)$ & $0(0 \%)$ & $0.00(0.00-0.00)$ & & & \\
\hline \multirow{2}{*}{ Dominant } & $\mathrm{A} / \mathrm{A}$ & $53(85.5 \%)$ & $53(85.5 \%)$ & 1.00 & \multirow[t]{2}{*}{0.95} & \multirow[t]{2}{*}{171.6} & \\
\hline & $\mathrm{A} / \mathrm{G}-\mathrm{G} / \mathrm{G}$ & $9(14.5 \%)$ & $9(14.5 \%)$ & $1.03(0.37-2.91)$ & & & \\
\hline \multirow[b]{2}{*}{ Recessive } & $\mathrm{A} / \mathrm{A}-\mathrm{A} / \mathrm{G}$ & $61(98.4 \%)$ & $62(100 \%)$ & 1.00 & \multirow[b]{2}{*}{0.23} & \multirow[b]{2}{*}{170.1} & \\
\hline & $\mathrm{G} / \mathrm{G}$ & $1(1.6 \%)$ & $0(0 \%)$ & $0.00(0.00-0.00)$ & & & \\
\hline \multirow{2}{*}{ Overdominant } & A/A-G/G & $54(87.1 \%)$ & $53(85.5 \%)$ & 1.00 & \multirow{2}{*}{0.73} & \multirow{2}{*}{171.5} & \\
\hline & A/G & $8(12.9 \%)$ & $9(14.5 \%)$ & $1.20(0.41-3.50)$ & & & \\
\hline \multirow[t]{2}{*}{ Log-additive } & - & - & - & $0.91(0.35-2.35)$ & 0.85 & 171.5 & \\
\hline & & & rs4986791 & & & & \\
\hline & $\mathrm{C} / \mathrm{C}$ & $53(85.5 \%)$ & $53(85.5 \%)$ & 1.00 & & & \\
\hline Codominant & $\mathrm{C} / \mathrm{T}$ & $8(12.9 \%)$ & $8(12.9 \%)$ & $1.00(0.33-2.97)$ & 0.98 & 173.5 & \\
\hline & $\mathrm{T} / \mathrm{T}$ & $1(1.6 \%)$ & $1(1.6 \%)$ & $1.36(0.08-23.62)$ & & & \\
\hline & $\mathrm{C} / \mathrm{C}$ & $53(85.5 \%)$ & $53(85.5 \%)$ & 1.00 & & & \\
\hline Dominant & $\mathrm{C} / \mathrm{T}-\mathrm{T} / \mathrm{T}$ & $9(14.5 \%)$ & $9(14.5 \%)$ & $1.03(0.37-2.91)$ & 0.95 & 171.6 & \\
\hline & $\mathrm{C} / \mathrm{C}-\mathrm{C} / \mathrm{T}$ & $61(98.4 \%)$ & $61(98.4 \%)$ & 1.00 & & & 0.17 \\
\hline Recessive & $\mathrm{T} / \mathrm{T}$ & $1(1.6 \%)$ & $1(1.6 \%)$ & $1.36(0.08-23.58)$ & 0.83 & 171.5 & \\
\hline & $\mathrm{C} / \mathrm{C}-\mathrm{T} / \mathrm{T}$ & $54(87.1 \%)$ & $54(87.1 \%)$ & 1.00 & & & \\
\hline Uverdominant & $\mathrm{C} / \mathrm{T}$ & $8(12.9 \%)$ & $8(12.9 \%)$ & $0.99(0.33-2.95)$ & 0.99 & 171.6 & \\
\hline Log-additive & - & - & - & $1.05(0.43-2.56)$ & 0.91 & 171.6 & \\
\hline & & & rs3775073 & & & & \\
\hline & $\mathrm{T} / \mathrm{T}$ & $12(19.4 \%)$ & $20(32.3 \%)$ & 1.00 & & & \\
\hline Codominant & $\mathrm{T} / \mathrm{C}$ & $32(51.6 \%)$ & $33(53.2 \%)$ & $0.71(0.29-1.75)$ & 0.092 & 168.8 & \\
\hline & $\mathrm{C} / \mathrm{C}$ & $18(29 \%)$ & $9(14.5 \%)$ & $0.31(0.10-0.94)$ & & & \\
\hline & $\mathrm{T} / \mathrm{T}$ & $12(19.4 \%)$ & $20(32.3 \%)$ & 1.00 & & & \\
\hline Dominant & $\mathrm{T} / \mathrm{C}-\mathrm{C} / \mathrm{C}$ & $50(80.7 \%)$ & $42(67.7 \%)$ & $0.56(0.24-1.32)$ & 0.18 & 169.8 & \\
\hline & $\mathrm{T} / \mathrm{T}-\mathrm{T} / \mathrm{C}$ & $44(71 \%)$ & $53(85.5 \%)$ & 1.00 & & & 0.72 \\
\hline Recessive & $\mathrm{C} / \mathrm{C}$ & $18(29 \%)$ & $9(14.5 \%)$ & $0.39(0.15-0.98)$ & 0.04 & 167.4 & \\
\hline Oyerdominant & $\mathrm{T} / \mathrm{T}-\mathrm{C} / \mathrm{C}$ & $30(48.4 \%)$ & $29(46.8 \%)$ & 1.00 & & 1713 & \\
\hline Overdominant & $\mathrm{T} / \mathrm{C}$ & $32(51.6 \%)$ & $33(53.2 \%)$ & $1.22(0.58-2.55)$ & 0.59 & 171.3 & \\
\hline Log-additive & - & - & - & $0.56(0.32-0.98)$ & 0.037 & 167.2 & \\
\hline & & & rs5743810 & & & & \\
\hline & $\mathrm{G} / \mathrm{G}$ & $35(56.5 \%)$ & $24(38.7 \%)$ & 1.00 & & & \\
\hline Codominant & $\mathrm{A} / \mathrm{G}$ & $25(40.3 \%)$ & $30(48.4 \%)$ & $1.57(0.73-3.38)$ & 0.09 & 168.8 & \\
\hline & $\mathrm{A} / \mathrm{A}$ & $2(3.2 \%)$ & $8(12.9 \%)$ & $5.19(0.97-27.93)$ & & & \\
\hline & $\mathrm{G} / \mathrm{G}$ & $35(56.5 \%)$ & $24(38.7 \%)$ & 1.00 & & & \\
\hline Dominant & $\mathrm{A} / \mathrm{G}-\mathrm{A} / \mathrm{A}$ & $27(43.5 \%)$ & $38(61.3 \%)$ & $1.83(0.87-3.84)$ & 0.11 & 169 & \\
\hline & G/G-A/G & $60(96.8 \%)$ & $54(87.1 \%)$ & 1.00 & & & 0.67 \\
\hline Recessive & $\mathrm{A} / \mathrm{A}$ & $2(3.2 \%)$ & $8(12.9 \%)$ & $4.17(0.81-21.53)$ & 0.062 & 168.1 & \\
\hline & G/G-A/A & 37 (59.7\%) & $32(51.6 \%)$ & 1.00 & & 1712 & \\
\hline Overdominant & $\mathrm{A} / \mathrm{G}$ & $25(40.3 \%)$ & $30(48.4 \%)$ & $1.26(0.61-2.64)$ & 0.53 & 171.2 & \\
\hline Log-additive & - & - & - & $1.87(1.02-3.44)$ & 0.039 & 167.3 & \\
\hline & & $T R$ & 1 rs2234246 & & & & \\
\hline & $\mathrm{C} / \mathrm{C}$ & $15(24.2 \%)$ & $18(29 \%)$ & 1.00 & & & \\
\hline Codominant & $\mathrm{C} / \mathrm{T}$ & $29(46.8 \%)$ & $33(53.2 \%)$ & $1.05(0.43-2.52)$ & 0.54 & 172.3 & \\
\hline & $\mathrm{T} / \mathrm{T}$ & $18(29 \%)$ & $11(17.7 \%)$ & $0.63(0.22-1.81)$ & & & \\
\hline & $\mathrm{C} / \mathrm{C}$ & $15(24.2 \%)$ & $18(29 \%)$ & 1.00 & & & \\
\hline Dominant & $\mathrm{C} / \mathrm{T}-\mathrm{T} / \mathrm{T}$ & $47(75.8 \%)$ & $44(71 \%)$ & $0.90(0.39-2.07)$ & 0.8 & 171.5 & \\
\hline & $\mathrm{C} / \mathrm{C}-\mathrm{C} / \mathrm{T}$ & $44(71 \%)$ & $51(82.3 \%)$ & 1.00 & & 1702 & 0.99 \\
\hline Recessive & $\mathrm{T} / \mathrm{T}$ & $18(29 \%)$ & $11(17.7 \%)$ & $0.61(0.25-1.47)$ & 0.27 & 170.3 & \\
\hline & $\mathrm{C} / \mathrm{C}-\mathrm{T} / \mathrm{T}$ & $33(53.2 \%)$ & $29(46.8 \%)$ & 1.00 & & & \\
\hline Overdominant & $\mathrm{C} / \mathrm{T}$ & $29(46.8 \%)$ & $33(53.2 \%)$ & $1.30(0.63-2.70)$ & 0.48 & 171.1 & \\
\hline Log-additive & - & - & - & $0.80(0.47-1.36)$ & 0.41 & 170.9 & \\
\hline & & $T R$ & 1 rs4711668 & & & & \\
\hline & $\mathrm{C} / \mathrm{C}$ & $26(41.9 \%)$ & $21(33.9 \%)$ & 1.00 & & & \\
\hline Codominant & $\mathrm{T} / \mathrm{C}$ & $30(48.4 \%)$ & $30(48.4 \%)$ & $1.29(0.58-2.85)$ & 0.46 & 172 & 0.85 \\
\hline & $\mathrm{T} / \mathrm{T}$ & $6(9.7 \%)$ & $11(17.7 \%)$ & $2.07(0.64-6.75)$ & & & \\
\hline
\end{tabular}


Table 1. Cont.

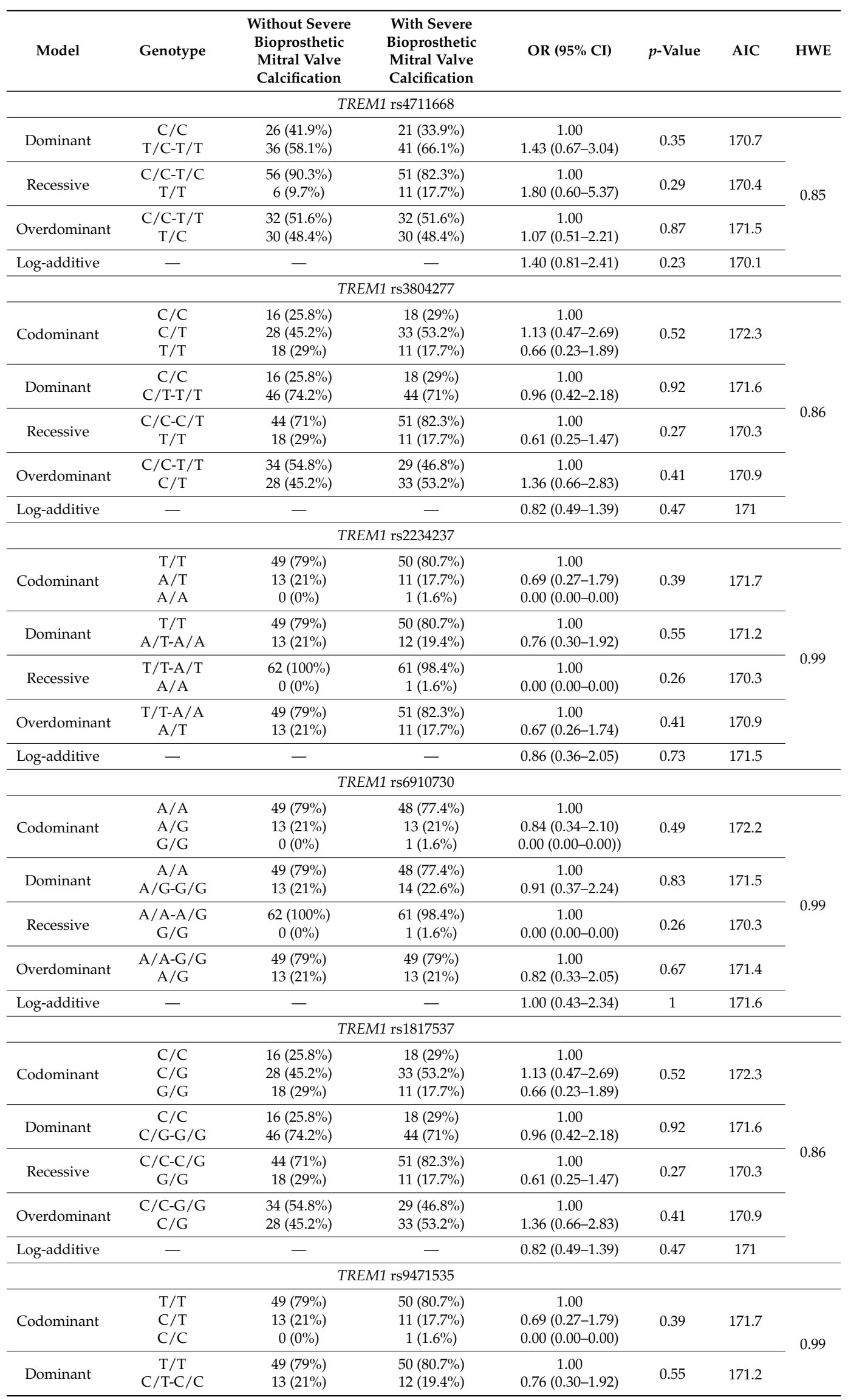


Table 1. Cont.

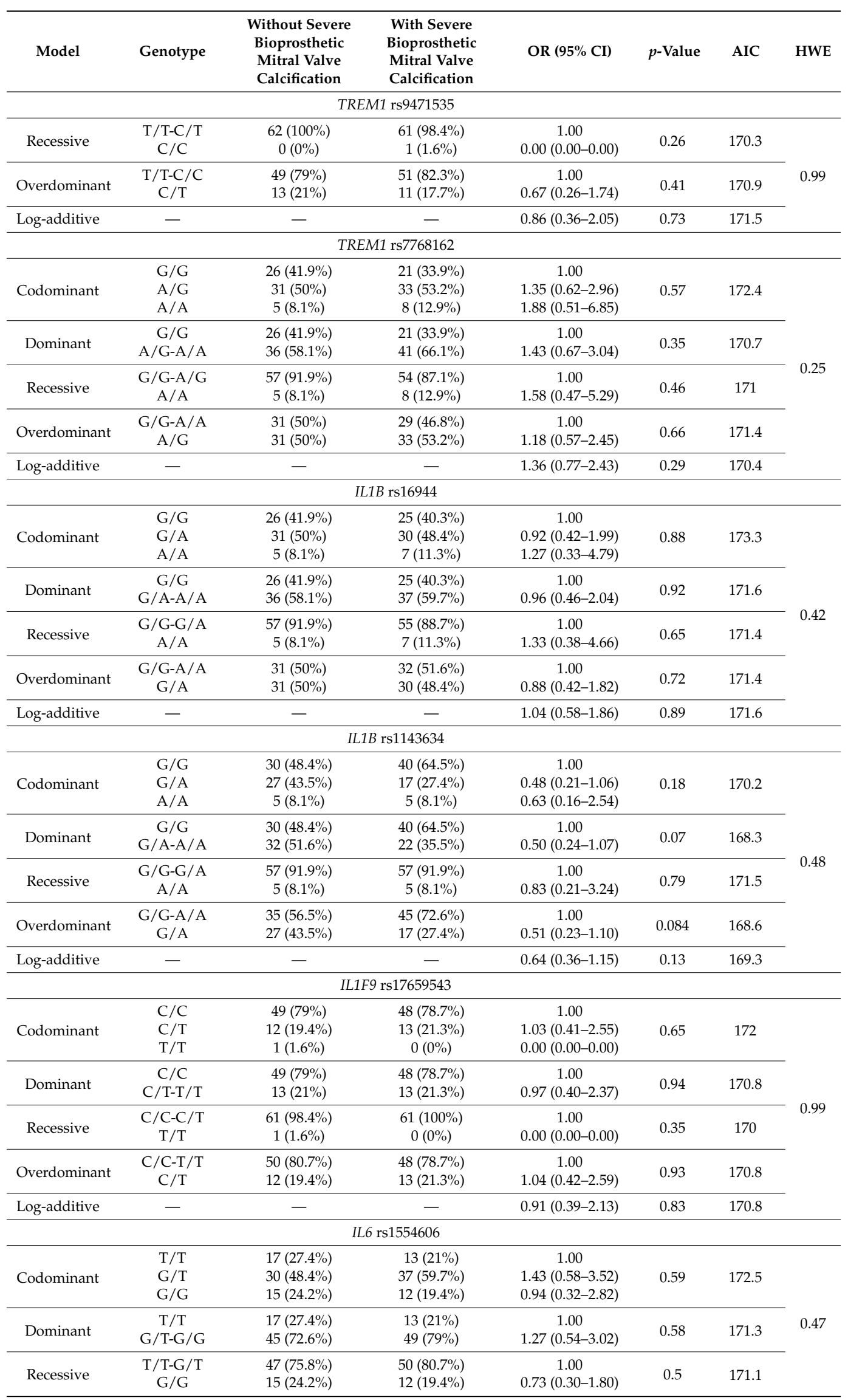


Table 1. Cont.

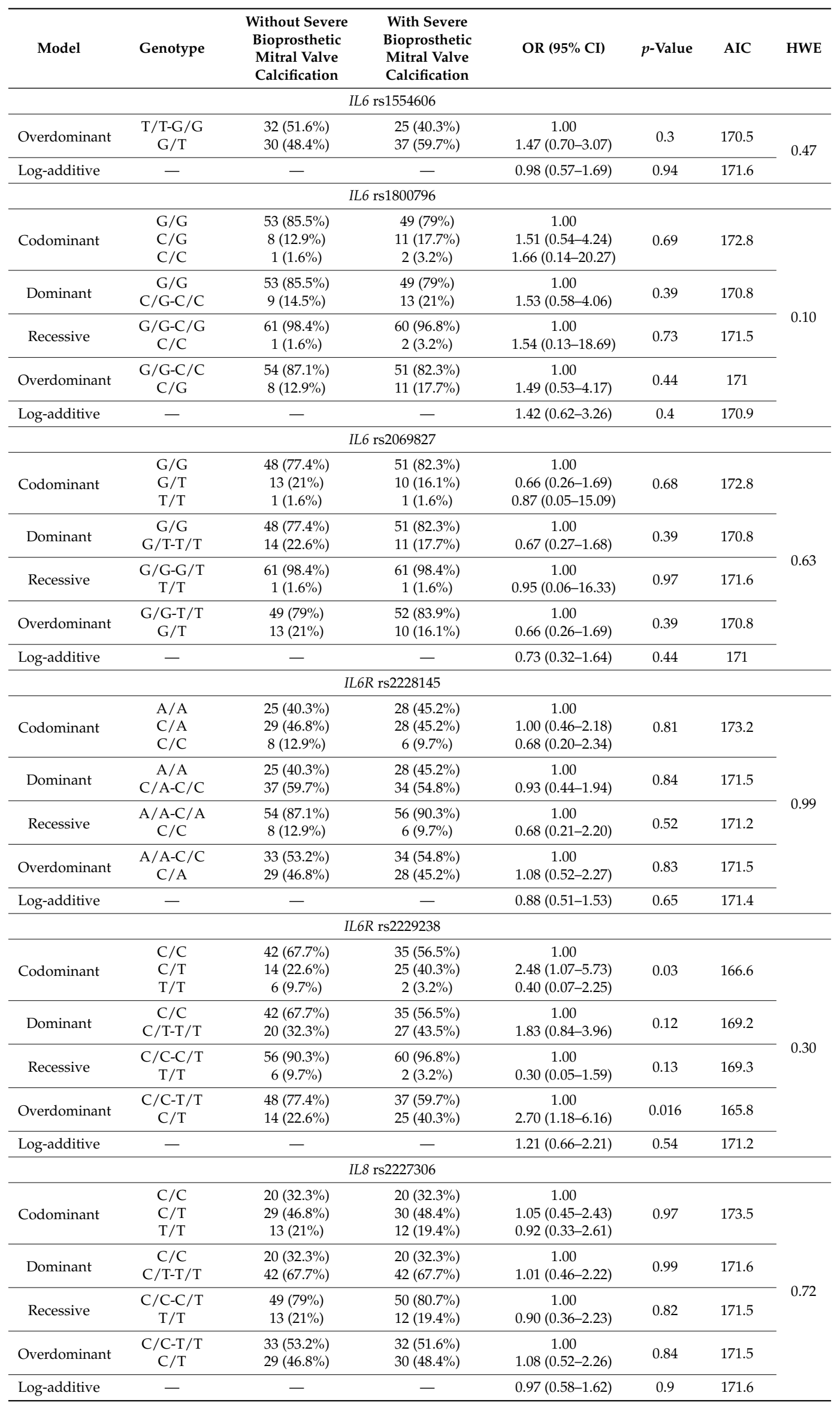


Table 1. Cont.

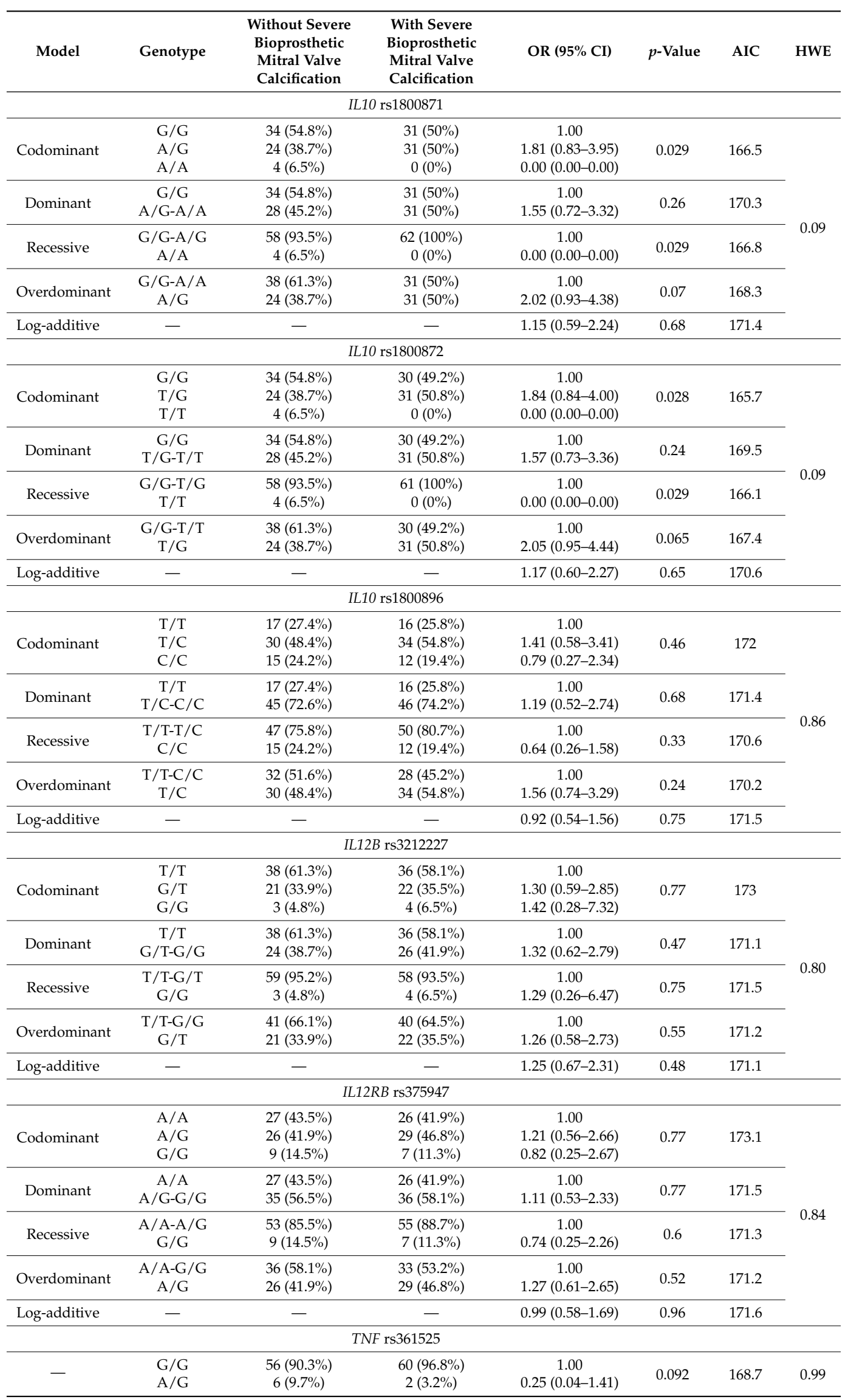


Table 1. Cont.

\begin{tabular}{|c|c|c|c|c|c|c|c|}
\hline Model & Genotype & $\begin{array}{l}\text { Without Severe } \\
\text { Bioprosthetic } \\
\text { Mitral Valve } \\
\text { Calcification }\end{array}$ & $\begin{array}{l}\text { With Severe } \\
\text { Bioprosthetic } \\
\text { Mitral Valve } \\
\text { Calcification }\end{array}$ & OR $(95 \%$ CI) & $p$-Value & AIC & HWE \\
\hline \multicolumn{8}{|c|}{ TNF rs1800629 } \\
\hline \multirow{3}{*}{ Codominant } & $\mathrm{G} / \mathrm{G}$ & $48(77.4 \%)$ & $54(87.1 \%)$ & 1.00 & \multirow{3}{*}{0.39} & \multirow{3}{*}{171.7} & \multirow{10}{*}{0.06} \\
\hline & $\mathrm{A} / \mathrm{G}$ & $11(17.7 \%)$ & $7(11.3 \%)$ & $0.60(0.21-1.73)$ & & & \\
\hline & $\mathrm{A} / \mathrm{A}$ & $3(4.8 \%)$ & $1(1.6 \%)$ & $0.31(0.03-3.19)$ & & & \\
\hline \multirow{2}{*}{ Dominant } & $\mathrm{G} / \mathrm{G}$ & $48(77.4 \%)$ & $54(87.1 \%)$ & 1.00 & \multirow{2}{*}{0.2} & \multirow{2}{*}{170} & \\
\hline & $\mathrm{A} / \mathrm{G}-\mathrm{A} / \mathrm{A}$ & $14(22.6 \%)$ & $8(12.9 \%)$ & $0.53(0.20-1.42)$ & & & \\
\hline \multirow{2}{*}{ Recessive } & G/G-A/G & $59(95.2 \%)$ & $61(98.4 \%)$ & 1.00 & \multirow{2}{*}{0.32} & \multirow[b]{2}{*}{170.6} & \\
\hline & $\mathrm{A} / \mathrm{A}$ & $3(4.8 \%)$ & $1(1.6 \%)$ & $0.34(0.03-3.42)$ & & & \\
\hline \multirow[b]{2}{*}{ Overdominant } & G/G-A/A & $51(82.3 \%)$ & $55(88.7 \%)$ & 1.00 & \multirow{2}{*}{0.38} & \multirow{2}{*}{170.8} & \\
\hline & A/G & $11(17.7 \%)$ & $7(11.3 \%)$ & $0.62(0.21-1.80)$ & & & \\
\hline \multirow[t]{2}{*}{ Log-additive } & - & - & - & $0.58(0.26-1.29)$ & 0.17 & 169.7 & \\
\hline & \multicolumn{4}{|c|}{ TNF rs1799964 } & & & \\
\hline & $\mathrm{T} / \mathrm{T}$ & $41(66.1 \%)$ & $41(66.1 \%)$ & 1.00 & & & \\
\hline Codominant & $\mathrm{C} / \mathrm{T}$ & $17(27.4 \%)$ & $18(29 \%)$ & $0.95(0.42-2.16)$ & 0.87 & 173.3 & \\
\hline & $\mathrm{C} / \mathrm{C}$ & $4(6.5 \%)$ & $3(4.8 \%)$ & $0.65(0.13-3.35)$ & & & \\
\hline Dominant & $\mathrm{T} / \mathrm{T}$ & $41(66.1 \%)$ & $41(66.1 \%)$ & 1.00 & & & \\
\hline Dominant & $\mathrm{C} / \mathrm{T}-\mathrm{C} / \mathrm{C}$ & $21(33.9 \%)$ & $21(33.9 \%)$ & $0.90(0.41-1.94)$ & 0.78 & 171.5 & \\
\hline & $\mathrm{T} / \mathrm{T}-\mathrm{C} / \mathrm{T}$ & $58(93.5 \%)$ & $59(95.2 \%)$ & 1.00 & & & 0.25 \\
\hline Recessive & $\mathrm{C} / \mathrm{C}$ & $4(6.5 \%)$ & $3(4.8 \%)$ & $0.66(0.13-3.33)$ & 0.61 & 171.3 & \\
\hline Oyerdominant & $\mathrm{T} / \mathrm{T}-\mathrm{C} / \mathrm{C}$ & $45(72.6 \%)$ & $44(71 \%)$ & 1.00 & & & \\
\hline Uverdominant & $\mathrm{C} / \mathrm{T}$ & $17(27.4 \%)$ & $18(29 \%)$ & $0.99(0.44-2.21)$ & 0.97 & 171.6 & \\
\hline Log-additive & - & - & - & $0.88(0.47-1.63)$ & 0.68 & 171.4 & \\
\hline & & & rs3093077 & & & & \\
\hline 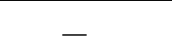 & $\mathrm{C} / \mathrm{C}$ & $55(88.7 \%)$ & $56(90.3 \%)$ & 1.00 & & & \\
\hline - & $\mathrm{A} / \mathrm{C}$ & $7(11.3 \%)$ & $6(9.7 \%)$ & $1.11(0.34-3.70)$ & 0.86 & 171.5 & 0.99 \\
\hline & & & rs1130864 & & & & \\
\hline & $\mathrm{G} / \mathrm{G}$ & $33(53.2 \%)$ & $22(35.5 \%)$ & 1.00 & & & \\
\hline Codominant & $\mathrm{A} / \mathrm{G}$ & $24(38.7 \%)$ & $31(50 \%)$ & $1.98(0.90-4.34)$ & 0.13 & 169.4 & \\
\hline & $\mathrm{A} / \mathrm{A}$ & $5(8.1 \%)$ & $9(14.5 \%)$ & $2.72(0.77-9.59)$ & & & \\
\hline & $\mathrm{G} / \mathrm{G}$ & $33(53.2 \%)$ & $22(35.5 \%)$ & 1.00 & & & \\
\hline Dominant & $\mathrm{A} / \mathrm{G}-\mathrm{A} / \mathrm{A}$ & $29(46.8 \%)$ & $40(64.5 \%)$ & $2.10(1.00-4.45)$ & 0.053 & 167.7 & \\
\hline Rococcivo & G/G-A/G & 57 (91.9\%) & $53(85.5 \%)$ & 1.00 & 027 & 1704 & 0.99 \\
\hline Recessive & $\mathrm{A} / \mathrm{A}$ & $5(8.1 \%)$ & $9(14.5 \%)$ & $1.93(0.58-6.36)$ & 0.27 & 170.4 & \\
\hline & G/G-A/A & $38(61.3 \%)$ & $31(50 \%)$ & 1.00 & & & \\
\hline Overdominant & $\mathrm{A} / \mathrm{G}$ & $24(38.7 \%)$ & $31(50 \%)$ & $1.61(0.77-3.38)$ & 0.2 & 170 & \\
\hline Log-additive & - & - & - & $1.76(1.00-3.09)$ & 0.051 & 167.6 & \\
\hline & & & $P$ rs1205 & & & & \\
\hline & $\mathrm{C} / \mathrm{C}$ & $19(30.6 \%)$ & $28(45.2 \%)$ & 1.00 & & & \\
\hline Codominant & $\mathrm{C} / \mathrm{T}$ & $32(51.6 \%)$ & $27(43.5 \%)$ & $0.42(0.18-0.98)$ & 0.09 & 168.8 & \\
\hline & $\mathrm{T} / \mathrm{T}$ & $11(17.7 \%)$ & $7(11.3 \%)$ & $0.41(0.13-1.30)$ & & & \\
\hline & $\mathrm{C} / \mathrm{C}$ & $19(30.6 \%)$ & $28(45.2 \%)$ & 1.00 & & & \\
\hline Dominant & $\mathrm{C} / \mathrm{T}-\mathrm{T} / \mathrm{T}$ & $43(69.3 \%)$ & $34(54.8 \%)$ & $0.42(0.19-0.93)$ & 0.028 & 166.8 & \\
\hline & $\mathrm{C} / \mathrm{C}-\mathrm{C} / \mathrm{T}$ & $51(82.3 \%)$ & $55(88.7 \%)$ & 1.00 & & & 0.99 \\
\hline Recessive & $\mathrm{T} / \mathrm{T}$ & $11(17.7 \%)$ & $7(11.3 \%)$ & $0.66(0.23-1.87)$ & 0.43 & 170.9 & \\
\hline & $\mathrm{C} / \mathrm{C}-\mathrm{T} / \mathrm{T}$ & $30(48.4 \%)$ & $35(56.5 \%)$ & 1.00 & & & \\
\hline Overdominant & $\mathrm{C} / \mathrm{T}$ & $32(51.6 \%)$ & $27(43.5 \%)$ & $0.55(0.25-1.17)$ & 0.12 & 169.1 & \\
\hline Log-additive & - & - & - & $0.58(0.34-1.02)$ & 0.052 & 167.8 & \\
\hline & & & rs1042031 & & & & \\
\hline & $\mathrm{C} / \mathrm{C}$ & $43(71.7 \%)$ & $42(70 \%)$ & 1.00 & & & \\
\hline Codominant & $\mathrm{C} / \mathrm{T}$ & $16(26.7 \%)$ & $16(26.7 \%)$ & $1.14(0.48-2.67)$ & 0.84 & 168.2 & \\
\hline & $\mathrm{T} / \mathrm{T}$ & $1(1.7 \%)$ & $2(3.3 \%)$ & $1.94(0.15-24.67)$ & & & \\
\hline & $\mathrm{C} / \mathrm{C}$ & $43(71.7 \%)$ & $42(70 \%)$ & 1.00 & & & \\
\hline Dominant & $\mathrm{C} / \mathrm{T}-\mathrm{T} / \mathrm{T}$ & $17(28.3 \%)$ & $18(30 \%)$ & $1.19(0.52-2.72)$ & 0.68 & 166.3 & \\
\hline & $\mathrm{C} / \mathrm{C}-\mathrm{C} / \mathrm{T}$ & $59(98.3 \%)$ & $58(96.7 \%)$ & 1.00 & & & 0.99 \\
\hline Recessive & $\mathrm{T} / \mathrm{T}$ & $1(1.7 \%)$ & $2(3.3 \%)$ & $1.89(0.15-23.70)$ & 0.62 & 166.3 & \\
\hline & $\mathrm{C} / \mathrm{C}-\mathrm{T} / \mathrm{T}$ & $44(73.3 \%)$ & $44(73.3 \%)$ & 1.00 & & & \\
\hline Overdominant & $\mathrm{C} / \mathrm{T}$ & $16(26.7 \%)$ & $16(26.7 \%)$ & $1.12(0.48-2.62)$ & 0.8 & 166.4 & \\
\hline Log-additive & - & - & - & $1.21(0.58-2.51)$ & 0.61 & 166.2 & \\
\hline
\end{tabular}


Table 1. Cont.

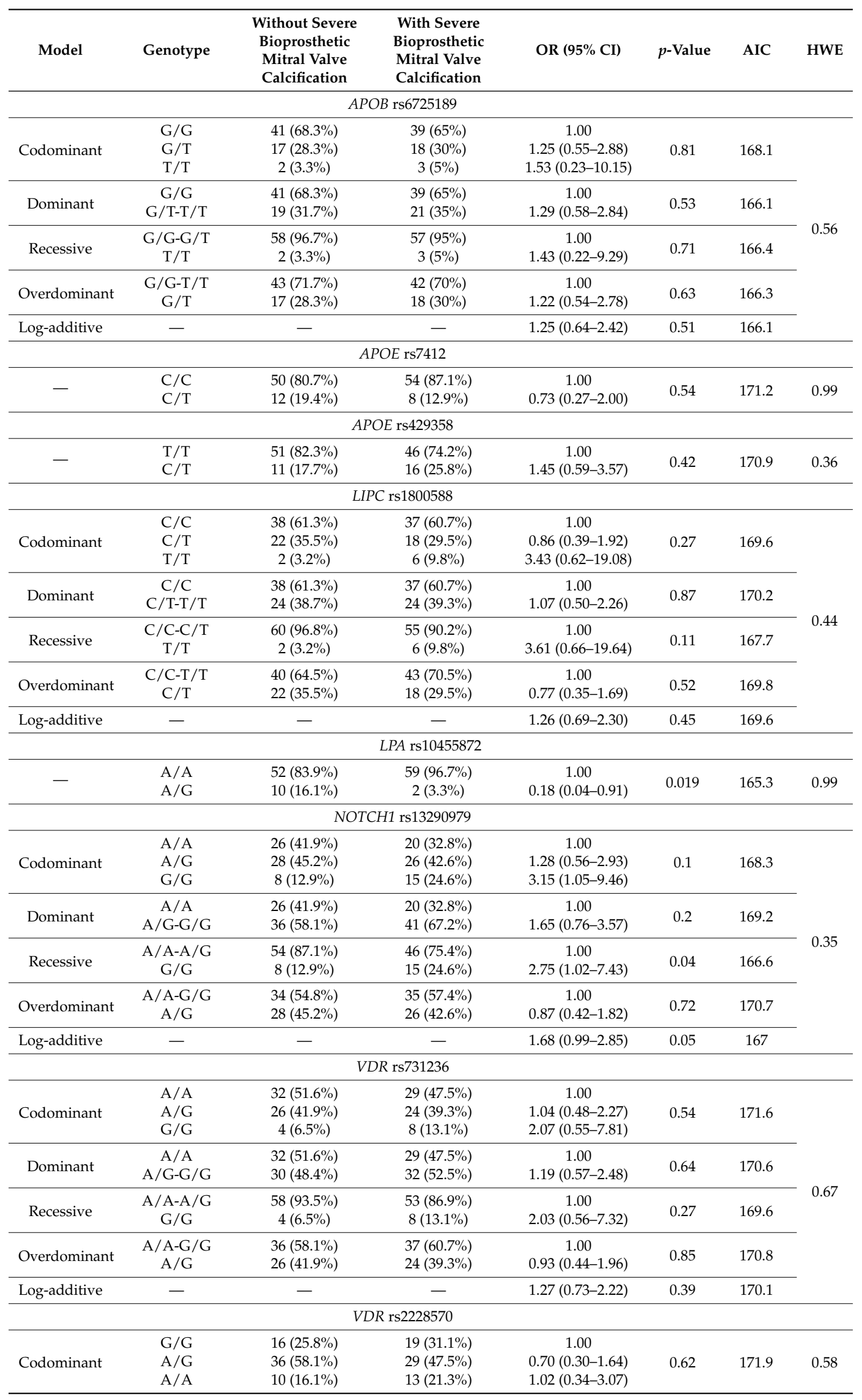


Table 1. Cont.

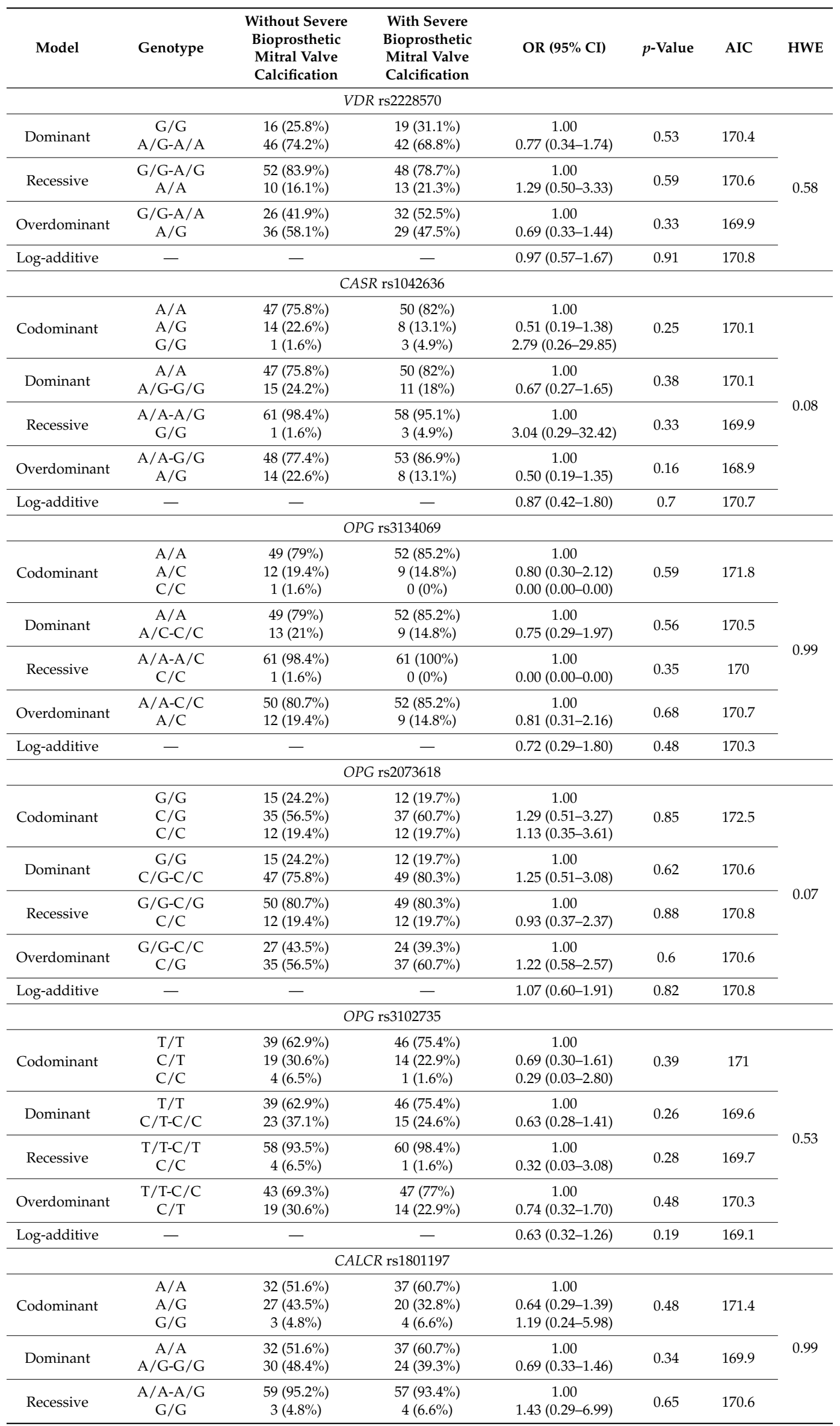


Table 1. Cont.

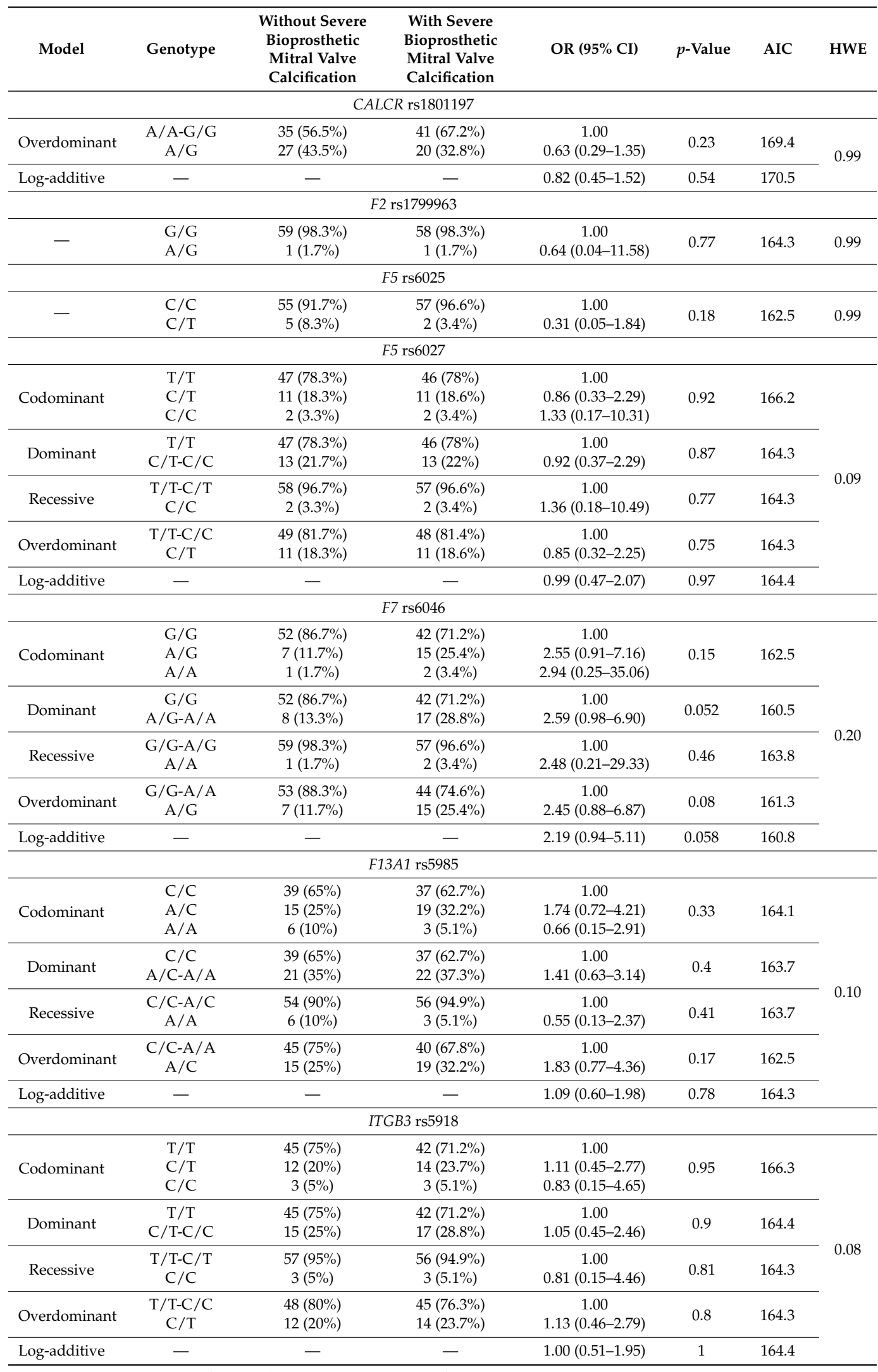

Here and below: TLR is for Toll-like receptor, TREM is for triggering receptor expressed on myeloid cells, IL is for interleukin, TNF is for tumor necrosis factor, CRP is for C-reactive protein, APO is for apolipoprotein, LIPC is for hepatic lipase, LPA is for lipoprotein (a), VDR is for vitamin D receptor, CASR is for calcium-sensing receptor, OPG is for osteoprotegerin, CALCR is for calcitonin receptor, ITGB is for integrin beta, OR is for odds ratio, CI is for confidence interval, AIC is for Akaike information criterion, and HWE is for Hardy-Weinberg equilibrium. 
The $C$ allele of the rs1800796 polymorphism within the TLR6 gene, the T allele of the rs1205 polymorphism within the $C R P$ gene, and the $\mathrm{G}$ allele of the rs 10455872 polymorphism within the $L P A$ gene were associated with decreased risk of severe bioprosthetic mitral valve calcification. In contrast, the A allele of the rs 5743810 polymorphism within the TLR6 gene, the C/T genotype of the rs2229238 polymorphism within the IL6R gene, the A/G genotype of the rs 1800871 polymorphism and the $\mathrm{T} / \mathrm{G}$ genotype of the rs1800872 polymorphism within the IL10 gene, and the G/G genotype of the rs13290979 polymorphism within the NOTCH1 gene were associated with increased risk of severe bioprosthetic mitral valve calcification. To perform an additional quality control step, we tested six non-relevant SNPs within the genes encoding coagulation factors and integrin beta 3, a protein responsible for platelet aggregation. Expectedly, we did not find any significant associations with severe bioprosthetic mitral valve calcification.

We then carried out a stepwise logistic regression to reveal independent predictive markers of severe bioprosthetic mitral valve calcification. Out of eight markers revealed by genetic association analysis, only three remained significant (Table 2).

Table 2. Brief description of the model predicting the risk of severe bioprosthetic mitral valve calcification after mitral valve replacement surgery, calculated by stepwise logistic regression.

\begin{tabular}{|c|c|}
\hline \multicolumn{2}{|r|}{ Clinical Markers } \\
\hline Gender & Male gender $\mathrm{OR}=2.80(95 \% \mathrm{CI}=1.23-6.38)$ \\
\hline Age & No statistically significant association \\
\hline Coronary artery disease & No statistically significant association \\
\hline Peripheral artery disease & No statistically significant association \\
\hline Arterial hypertension & No statistically significant association \\
\hline Diabetes mellitus & No statistically significant association \\
\hline \multicolumn{2}{|r|}{ Genomic Markers } \\
\hline rs3775073 (TLR6) & Carriers of $\mathrm{T} / \mathrm{T}$ genotype: $\mathrm{OR}=3.33(95 \% \mathrm{CI}=1.14-9.75)$ \\
\hline rs2229238 (IL6R) & Carriers of $\mathrm{C} / \mathrm{T}$ genotype: $\mathrm{OR}=3.70(95 \% \mathrm{CI}=1.48-9.22)$ \\
\hline rs10455872 (LPA) & Carriers of A/A genotype: $\mathrm{OR}=5.67(95 \% \mathrm{CI}=1.19-27.09)$ \\
\hline rs5743810 (TLR6) & No statistically significant association \\
\hline rs1800871 (IL10) & No statistically significant association \\
\hline rs1800872 (IL10) & No statistically significant association \\
\hline rs1205 (CRP) & No statistically significant association \\
\hline rs13290979 (NOTCH1) & No statistically significant association \\
\hline \multicolumn{2}{|r|}{ General Evaluation } \\
\hline Sensitivity & $59.68 \%$ (37 true; 25 false-negatives) \\
\hline Specificity & $74.19 \%$ (46 true; 16 false-positives) \\
\hline Percent of cases correctly classified & $66.94 \%$ \\
\hline Area under the ROC curve & $0.73(95 \% \mathrm{CI}=0.64-0.81)$ \\
\hline Standard error & 0.045 \\
\hline
\end{tabular}

A final model for prediction of severe bioprosthetic mitral valve calcification included male gender, the T/T genotype of the rs 3775073 polymorphism within the TLR6 gene, the C/T genotype of the rs2229238 polymorphism within the IL6R gene, and the A/A genotype of the rs 10455872 polymorphism within the LPA gene. The area under the ROC curve of 0.73 demonstrated the fair predictive value of the model.

\section{Discussion}

Previous studies vaguely uncovered the genetic susceptibility to mitral annular calcification. Novaro et al. [10] and Tangri et al. [11] did not detect significant associations between polymorphisms within apoE (gene encoding apolipoprotein E), Klotho, $\beta$-Klotho, and FGF-23 (genes encoding proteins constituting one of the calcium phosphate homeostasis pathways) genes and mitral annular calcification. Davutoglu and Nacak [12] reported that the I allele of the rs4340 polymorphism within the $A C E$ gene (encoding angiotensin-converting enzyme) correlated with a higher risk of mitral 
annular calcification. Moreover, a study by Thanassoulis et al. [13] revealed two IL1F9 (gene encoding IL-36 /IL-1F9 protein) gene polymorphisms, rs17659543 and rs13415097, being significantly associated with higher risk of mitral annular calcification.

However, there are no published data on genetic susceptibility to bioprosthetic mitral valve calcification. In addition, there is no any model for the prediction of bioprosthetic mitral valve calcification. Here we identified the T/T genotype of the rs3775073 polymorphism within the TLR6 gene, the $\mathrm{C} / \mathrm{T}$ genotype of the rs2229238 polymorphism within the IL6R gene, and the A/A genotype of the rs 10455872 polymorphism within the LPA gene as the independent predictive markers of severe bioprosthetic mitral valve calcification. Moreover, we developed a predictive model with the fair discriminative power. Nevertheless, area under the receiver operating characteristic (ROC) curve of 0.73 indicates a number of other relevant predictive markers to be discovered.

A previous study by our research group found that the $C / T$ genotype of the rs2229238 polymorphism within the IL6R gene is significantly associated with a higher IL-6 plasma level compared to the $\mathrm{C} / \mathrm{C}$ and $\mathrm{T} / \mathrm{T}$ genotypes [14]. It is worth noting that IL-6 is associated with heart valve calcification in general and with mitral annular calcification in particular $[15,16]$. Therefore, we hypothesize that the C/T genotype of the rs2229238 polymorphism within the IL6R gene may increase IL-6 plasma level and may thus promote bioprosthetic mitral valve calcification.

Our study had a considerable shortcoming: we recruited a relatively small sample due to a limited number of mitral valve replacements. However, we tested six irrelevant SNPs for the occasional associations, expectedly with a negative result. This approach was used to increase statistical confidence when using a small sample size.

Our findings may have clinical applications. A genomics-based model for the prediction of severe bioprosthetic mitral valve calcification can be used in choosing between mechanical and bioprosthetic mitral valves for mitral valve replacement surgery. For carriers of the high risk genotypes, mechanical heart valves which are resistant to calcification may be an appropriate option (reviewed by Bre et al. [17]). Further investigations on larger samples are necessary to confirm our results.

\section{Materials and Methods}

\subsection{Population}

Inclusion criteria were: (1) living in Kemerovo Region for $\geq 2$ generations; (2) Russian ethnicity; (3) mitral valve replacement surgery due to mitral valve disease; and (4) written informed consent. Exclusion criteria were: (1) belonging to the immigrant or aboriginal populations; (2) previous cancer diagnosis; (3) concomitant mental disorders and/or autoimmune diseases; and (4) refusal to sign a written informed consent.

We recruited 140 patients admitted to our Research Institute who underwent mitral valve replacement surgery due to mitral valve disease in 2006-2007. After exclusion of 16 patients due to the above-mentioned criteria, the study group finally included 124 patients (Table 3).

Table 3. Clinical features of the patients who underwent mitral valve replacement surgery.

\begin{tabular}{cc}
\hline Feature & Value, $\boldsymbol{n} \mathbf{( \% )}$ \\
\hline Male gender & $50(40.32 \%)$ \\
Age $\geq 50$ years & $65(52.42 \%)$ \\
Mitral stenosis and /or regurgitation with New York & $54(43.55 \%)$ \\
Heart Association functional class III-IV symptoms & $14(11.29 \%)$ \\
Coronary artery disease & $6(4.84 \%)$ \\
Peripheral artery disease & $38(30.64 \%)$ \\
Arterial hypertension & $8(6.45 \%)$ \\
Diabetes mellitus & $62(50.00 \%)$ \\
Severe bioprosthetic mitral valve & \\
\hline
\end{tabular}


Half of them $(n=62)$ had severe bioprosthetic mitral valve calcification within 8 years post-implantation and therefore represented a case group; remaining subjects $(n=62)$ without severe bioprosthetic mitral valve calcification were considered as the controls (Table 4). The local ethical committee approved the study protocol. All the participants provided written informed consent after the study was fully explained.

Table 4. Basic and echocardiography characteristics of the study population.

\begin{tabular}{|c|c|c|c|c|}
\hline Feature & $\begin{array}{c}\text { Without Severe } \\
\text { Bioprosthetic Mitral } \\
\text { Valve Calcification }\end{array}$ & $\begin{array}{l}\text { With Severe Bioprosthetic } \\
\text { Mitral Valve Calcification }\end{array}$ & Total & $p$ Value \\
\hline \multicolumn{5}{|c|}{ Basic characteristics } \\
\hline Sample size & $62(50.00 \%)$ & $62(50.00 \%)$ & $124(100.00 \%)$ & \multirow{3}{*}{0.09} \\
\hline Mean age & $50.60(48.12-53.08)$ & $47.81(45.68-49.94)$ & $49.20(47.57-50.83)$ & \\
\hline $\begin{array}{l}\text { Standard deviation } \\
\text { of mean age }\end{array}$ & 9.76 & 8.39 & 9.17 & \\
\hline Male gender & $19(30.64 \%)$ & $31(50.00 \%)$ & $50(40.32 \%)$ & \multirow{2}{*}{0.03} \\
\hline Female gender & $43(69.36 \%)$ & $31(50.00 \%)$ & $74(59.68 \%)$ & \\
\hline \multicolumn{5}{|c|}{ Echocardiography characteristics } \\
\hline Left atrial diameter, $\mathrm{cm}$ & $6.70(6.43-7.01)$ & $5.51(5.22-5.69)$ & $6.10(5.82-6.35)$ & 0.02 \\
\hline $\begin{array}{l}\text { Left ventricular } \\
\text { end-diastolic diameter, } \mathrm{cm}\end{array}$ & $5.42(5.23-5.56)$ & $5.37(5.17-5.50)$ & $5.39(5.20-5.53)$ & 0.81 \\
\hline $\begin{array}{c}\text { Left ventricular } \\
\text { end-systolic diameter, cm }\end{array}$ & $3.23(3.05-3.39)$ & $3.41(3.26-3.51)$ & $3.32(3.15-3.45)$ & 0.36 \\
\hline $\begin{array}{l}\text { Left ventricular } \\
\text { end-diastolic volume, } \mathrm{cm}^{3}\end{array}$ & $139.03(136.12-143.15)$ & $136.56(134.01-139.76)$ & $137.79(135.06-141.45)$ & 0.82 \\
\hline $\begin{array}{l}\text { Left ventricular } \\
\text { end-systolic volume, } \mathrm{cm}^{3}\end{array}$ & $40.23(38.23-41.98)$ & $45.14(43.24-47.12)$ & $42.68(40.73-44.55)$ & 0.03 \\
\hline $\begin{array}{l}\text { Interventricular septal } \\
\text { thickness, cm }\end{array}$ & $1.04(0.97-1.12)$ & $1.08(1.02-1.15)$ & $1.06(0.99-1.13)$ & 0.89 \\
\hline $\begin{array}{l}\text { Left ventricular posterior } \\
\text { wall thickness, cm }\end{array}$ & $1.03(0.95-1.08)$ & $1.11(1.00-1.18)$ & $1.07(0.97-1.13)$ & 0.72 \\
\hline $\begin{array}{l}\text { Left ventricular ejection } \\
\text { fraction, } \%\end{array}$ & $71.00(67.00-74.00)$ & $65.00(61.00-68.00)$ & $68.00(64.00-71.00)$ & 0.03 \\
\hline Right atrial diameter, cm & $6.00(5.87-6.16)$ & $4.70(4.62-4.88)$ & $5.35(5.24-5.52)$ & 0.03 \\
\hline $\begin{array}{l}\text { Right ventricular } \\
\text { diameter, } \mathrm{cm}\end{array}$ & $2.09(2.01-2.17)$ & $2.03(1.95-2.14)$ & $2.06(1.98-2.15)$ & 0.76 \\
\hline Aortic root diameter, $\mathrm{cm}$ & $3.30(3.12-3.49)$ & $3.32(3.14-3.50)$ & $3.31(3.13-3.49)$ & 0.93 \\
\hline Mitral valve area, $\mathrm{cm}^{2}$ & $1.72(1.64-1.79)$ & $1.41(1.35-1.47)$ & $1.56(1.49-1.63)$ & 0.02 \\
\hline
\end{tabular}

The diagnosis of mitral valve disease and decision on mitral valve replacement surgery were performed in accordance with the respective American guidelines [18]. For the mitral valve replacement, we used KemCor and PeriCor bioprosthetic valves (NeoCor, Russian Federation) crosslinked with ethylene glycol diglycidyl ether for conferring resistance to oxidation and enzymatic degradation [19]. Functional conditions of the bioprosthetic valves were annually assessed by echocardiography. After the explantation of failing bioprosthesis (Figure 1a), bioprosthetic mitral valve calcification was verified by von Kossa staining (Figure 1b) and scanning electron microscopy (Figure 1c). 

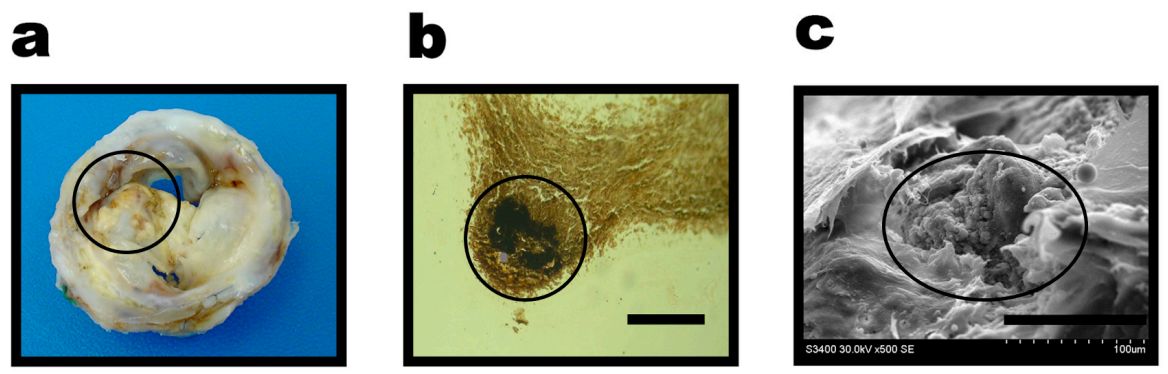

Figure 1. Bioprosthetic valve calcification: (a) explanted bioprosthetic heart valve; (b) von Kossa staining, scale bar $=50 \mu \mathrm{m}$; (c) scanning electron microscopy. Calcified areas are indicated as black circles.

The study workflow is shown in the Figure 2.

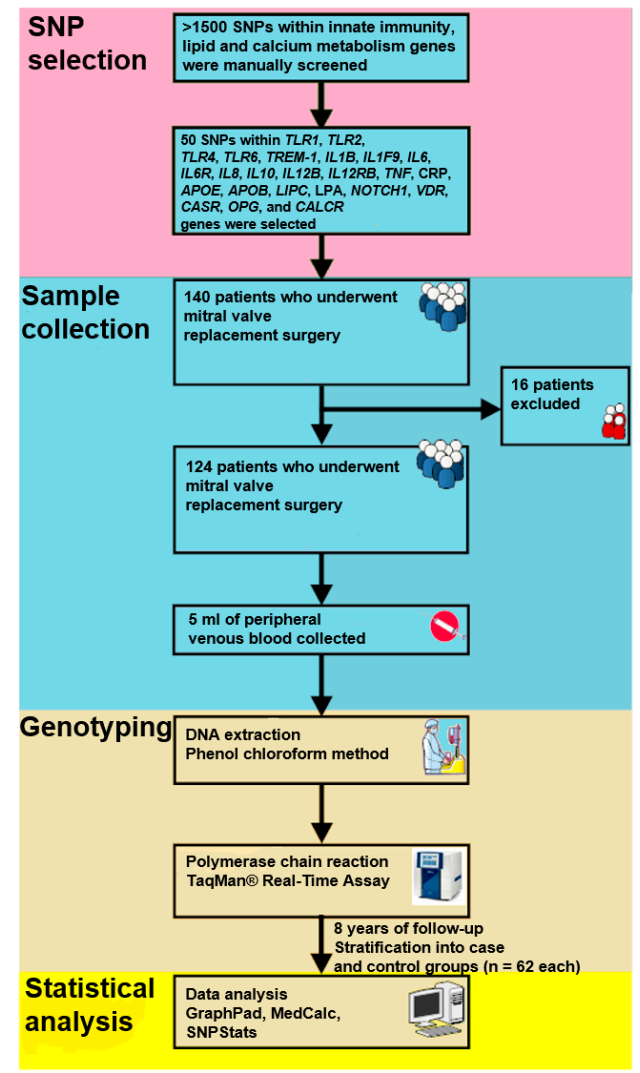

Figure 2. Study workflow.

\subsection{SNP Selection and Genotyping}

For this study, we defined four main criteria for SNP selection: (1) location within innate immunity, lipid metabolism, or calcium metabolism genes; (2) minor allele frequency $\geq 5 \%$ for Russian population tested with HapMap; (3) functional consequences; and (4) few or no studies on the role of the SNP in mitral valve calcification. The National Center for Biotechnology Information dbSNP, SNPinfo, and SNPnexus databases were utilized for the SNP selection [20,21]. In total, we selected 50 SNPs within 24 genes (Table 5).

The procedures of DNA extraction and genotyping were the same as previously described [22-24]. Table 5 demonstrates the sequence-specific primers for genotyped SNPs. Laboratory staff was blinded to patient status, and one-tenth of the samples was repeatedly genotyped for quality control. 
Table 5. Features of the genotyped polymorphisms.

\begin{tabular}{|c|c|c|c|c|}
\hline $\begin{array}{l}\text { Single Nucleotide } \\
\text { Polymorphism }\end{array}$ & $\begin{array}{l}\text { Nucleotide } \\
\text { Substitution }\end{array}$ & $\begin{array}{l}\text { Chromosomal } \\
\text { Position }\end{array}$ & $\begin{array}{l}\text { Amino Acid } \\
\text { Substitution }\end{array}$ & $\begin{array}{c}\text { Forward } 5^{\prime}-3^{\prime} \text { and } \\
\text { Reverse } 3^{\prime}-5^{\prime} \text { Polymerase } \\
\text { Chain Reaction Primers }\end{array}$ \\
\hline \multicolumn{5}{|c|}{ TLR1 gene } \\
\hline rs5743551 & $\mathrm{T}>\mathrm{C}$ & 38807654 & $5^{\prime}$-upstream & $\begin{array}{l}\text { F: agtgggcagggcagtaagggaagct } \\
\text { R: ctcagcactctgaattcctgttttt }\end{array}$ \\
\hline rs5743611 & $C>G$ & 38800214 & Arg80Thr & $\begin{array}{l}\text { F: aacactgatatcaagatactggatt } \\
\text { R: tattatgagaaattatcaaaatcct }\end{array}$ \\
\hline \multicolumn{5}{|c|}{ TLR2 gene } \\
\hline rs3804099 & $\mathrm{T}>\mathrm{C}$ & 154624656 & Asn199Asn & $\begin{array}{l}\text { F: caaaaagtttgaagtcaattcagaa } \\
\text { R: gtaagtcatctgatccttcatatga }\end{array}$ \\
\hline rs5743708 & $\mathrm{G}>\mathrm{A}$ & 154626317 & Arg753Gln & $\begin{array}{l}\text { F: aagccattccccagcgcttctgcaagctgc } \\
\text { R: gaagataatgaacaccaagacctacctgga }\end{array}$ \\
\hline \multicolumn{5}{|c|}{ TLR4 gene } \\
\hline rs4986790 & $A>G$ & 120475302 & Asp299Gly & $\begin{array}{l}\text { F: gattagcatacttagactactacctcgatg } \\
\text { R: attattgacttatttaattgtttgacaaat }\end{array}$ \\
\hline rs4986791 & $\mathrm{C}>\mathrm{T}$ & 120475602 & Thr399Ile & $\begin{array}{l}\text { F: gttgctgttctcaaagtgattttgggacaa } \\
\text { R: agcctaaagtatttagatctgagcttcaat }\end{array}$ \\
\hline \multicolumn{5}{|c|}{ TLR6 gene } \\
\hline rs3775073 & $\mathrm{T}>\mathrm{C}$ & 38829832 & Lys421Lys & $\begin{array}{l}\text { F: cactatactctcaacccaagtgcagttttc } \\
\text { R: ttatgtctaccagattccaaagaattccagc }\end{array}$ \\
\hline rs5743810 & $A>G$ & 38830350 & Ser249Pro & $\begin{array}{l}\text { F: ttgagggtaaaattcagtaaggttg } \\
\text { R: acctctggtgagttctgataaaaat }\end{array}$ \\
\hline \multicolumn{5}{|c|}{ TREM-1 gene } \\
\hline rs1817537 & $C>G$ & 41244567 & intronic & $\begin{array}{l}\text { F: acacagggacagacagatggcaatggaaca } \\
\text { R: aaggccagatgcagagccagtgctatgcag }\end{array}$ \\
\hline rs3804277 & $\mathrm{C}>\mathrm{T}$ & 41245172 & intronic & $\begin{array}{l}\text { F: ccagcatctctctcacccctcacatggtgg } \\
\text { R: cactcagcatcctcagcatctgcccegatt }\end{array}$ \\
\hline rs6910730 & $A>G$ & 41246633 & 3'-downstream & $\begin{array}{l}\text { F: catggagcaacaccaaggtctaggggcaag } \\
\text { R: aatctaggatggattcgtgctgacttccca }\end{array}$ \\
\hline rs7768162 & $A>G$ & 41255511 & $5^{\prime}$-upstream & $\begin{array}{l}\text { F: aaagattcctactgctaaataaacaaaaaa } \\
\text { R: taacttggtttcttcaaaggaattgaaata }\end{array}$ \\
\hline rs2234246 & $\mathrm{C}>\mathrm{T}$ & 41243740 & $3^{\prime}$-UTR & $\begin{array}{l}\text { F: ggaaggtgagacgctgactttagaaatagc } \\
\text { R: ggtgattacagatttaattcatgttattaa }\end{array}$ \\
\hline rs4711668 & $\mathrm{T}>\mathrm{C}$ & 41246473 & 3'-downstream & $\begin{array}{l}\text { F: gctagtgtggattccactttccagactgga } \\
\text { R: ttggctgaaaggatagttcatattagatga }\end{array}$ \\
\hline rs9471535 & $\mathrm{T}>\mathrm{C}$ & 41255490 & 5'-upstream & $\begin{array}{l}\text { F: aaaatttttaaatttaaataaaaagattcc } \\
\text { R: ctgctaaataaacaaaaaaataacttggtt }\end{array}$ \\
\hline rs2234237 & $\mathrm{T}>\mathrm{A}$ & 41250466 & Thr25Ser & $\begin{array}{l}\text { F: gcccctctttcagttcatacttttcctcag } \\
\text { R: aatttagttgcagctcggagttctataagc }\end{array}$ \\
\hline \multicolumn{5}{|c|}{ IL1B gene } \\
\hline rs16944 & $A>G$ & 113594867 & $5^{\prime}$-upstream & $\begin{array}{l}\text { F: taccttgggtgctgttctctgcctc } \\
\text { R: ggagctctctgtcaattgcaggagc }\end{array}$ \\
\hline rs1143634 & $\mathrm{G}>\mathrm{A}$ & 113590390 & Phe105Phe & $\begin{array}{c}\text { F: cataagcctcgttatcccatgtgtc } \\
\text { R: aagaagataggttctgaaatgtgga }\end{array}$ \\
\hline \multicolumn{5}{|c|}{ IL1F9 gene } \\
\hline rs17659543 & $\mathrm{C}>\mathrm{T}$ & 113716306 & Not announced & $\begin{array}{l}\text { F: tgtacctggacaagaggcataaattggggc } \\
\text { R: gtcttaggaaagcagatatacagccatcct }\end{array}$ \\
\hline \multicolumn{5}{|c|}{ IL6 gene } \\
\hline rs1554606 & $\mathrm{T}>\mathrm{G}$ & 22768707 & intronic & $\begin{array}{l}\text { F: ttagttcatcctgggaaaggtactc } \\
\text { R: cagggccttttcctctctggctgc }\end{array}$ \\
\hline
\end{tabular}


Table 5. Cont.

\begin{tabular}{|c|c|c|c|c|}
\hline $\begin{array}{l}\text { Single Nucleotide } \\
\text { Polymorphism }\end{array}$ & $\begin{array}{l}\text { Nucleotide } \\
\text { Substitution }\end{array}$ & $\begin{array}{l}\text { Chromosomal } \\
\text { Position }\end{array}$ & $\begin{array}{l}\text { Amino Acid } \\
\text { Substitution }\end{array}$ & $\begin{array}{c}\text { Forward } 5^{\prime}-3^{\prime} \text { and } \\
\text { Reverse } 3^{\prime}-5^{\prime} \text { Polymerase } \\
\text { Chain Reaction Primers }\end{array}$ \\
\hline \multicolumn{5}{|c|}{ IL6 gene } \\
\hline rs1800796 & $\mathrm{G}>\mathrm{C}$ & 22766246 & $5^{\prime}$-upstream & $\begin{array}{l}\text { F: atggccaggcagttctacaacagcc } \\
\text { R: ctcacagggagagccagaacacaga }\end{array}$ \\
\hline rs2069827 & $\mathrm{G}>\mathrm{T}$ & 22765456 & $5^{\prime}$-upstream & $\begin{array}{l}\text { F: gcccaacagaggtcactgttttatc } \\
\text { R: atcttgaagagatctcttcttagca }\end{array}$ \\
\hline \multicolumn{5}{|c|}{ IL6R gene } \\
\hline rs2228145 & $\mathrm{A}>\mathrm{T} / \mathrm{C}$ & 154426970 & Asp358Val/Ala & $\begin{array}{l}\text { F: aattttttttttaacctagtgcaag } \\
\text { R: ttcttcttcagtaccactgcccaca }\end{array}$ \\
\hline rs2229238 & $\mathrm{T}>\mathrm{C}$ & 154437896 & $3^{\prime}$-UTR & $\begin{array}{l}\text { F: ccagcagcctggaccctgtggatga } \\
\text { R: aaaacacaaacgggctcagcaaaag }\end{array}$ \\
\hline \multicolumn{5}{|c|}{ IL8 gene } \\
\hline rs2227306 & $\mathrm{C}>\mathrm{T}$ & 74607055 & intronic & $\begin{array}{l}\text { F: aactctaactctttatataggaagt } \\
\text { R: gttcaatgttgtcagttatgactgt }\end{array}$ \\
\hline \multicolumn{5}{|c|}{ IL10 gene } \\
\hline rs1800871 & $A>G$ & 206946634 & $5^{\prime}$-upstream & $\begin{array}{l}\text { F: agtgagcaaactgaggcacagagat } \\
\text { R: ttacatcacctgtacaagggtacac }\end{array}$ \\
\hline rs1800872 & $\mathrm{T}>\mathrm{G}$ & 206946407 & 5'-upstream & $\begin{array}{c}\text { F: ttttactttccagagactggcttcctacag } \\
\text { R: acaggcggggtcacaggatgtgttccaggc }\end{array}$ \\
\hline rs1800896 & $\mathrm{T}>\mathrm{C}$ & 206946897 & $5^{\prime}$-upstream & $\begin{array}{l}\text { F: tcctcttacctatccctacttcccc } \\
\text { R: tcccaaagaagccttagtagtgttg }\end{array}$ \\
\hline \multicolumn{5}{|c|}{ IL12B gene } \\
\hline rs3212227 & $\mathrm{T}>\mathrm{G}$ & 158742950 & $3^{\prime}$-UTR & $\begin{array}{l}\text { F: attgtttcaatgagcatttagcatc } \\
\text { R: aactatacaaatacagcaaagatat }\end{array}$ \\
\hline \multicolumn{5}{|c|}{ IL12RB gene } \\
\hline rs375947 & $A>G$ & 18180451 & Met365Thr & $\begin{array}{l}\text { F: aggctgccattcaatgcaatacgtc } \\
\text { R: tgctctgagcccgggctggccaata }\end{array}$ \\
\hline \multicolumn{5}{|c|}{ TNF gene } \\
\hline rs361525 & $\mathrm{G}>\mathrm{A}$ & 31543101 & $5^{\prime}$-upstream & $\begin{array}{l}\text { F: ggcccagaagacccccctcggaatc } \\
\text { R: gagcagggaggatggggagtgtgag }\end{array}$ \\
\hline rs1800629 & $\mathrm{G}>\mathrm{A}$ & 31543031 & $5^{\prime}$-upstream & $\begin{array}{l}\text { F: gaggcaataggttttgaggggcatg } \\
\text { R: ggacggggttcagcctccagggtcc }\end{array}$ \\
\hline rs1799964 & $\mathrm{T}>\mathrm{C}$ & 31542308 & $3^{\prime}$-downstream & $\begin{array}{l}\text { F: gcaggggaagcaaaggagaagctgagaaga } \\
\text { R: gaaggaaaagtcagggtctggaggggcggg }\end{array}$ \\
\hline \multicolumn{5}{|c|}{$C R P$ gene } \\
\hline rs3093077 & $\mathrm{A}>\mathrm{C}$ & 159679636 & Not announced & $\begin{array}{l}\text { F: ggaatccaggcaagtacgacaaccc } \\
\text { R: tctgagactagtgggcagttgtcct }\end{array}$ \\
\hline rs1130864 & $\mathrm{G}>\mathrm{A}$ & 159683091 & $3^{\prime}$-UTR & $\begin{array}{l}\text { F: cctcaaattctgattcttttggacc } \\
\text { R: tttcccagcatagttaacgagctcc }\end{array}$ \\
\hline rs1205 & $\mathrm{C}>\mathrm{T}$ & 159682233 & $3^{\prime}$-UTR & $\begin{array}{l}\text { F: acttccagtttggcttctgtcctca } \\
\text { R: agtctctctccatgtggcaaacaag }\end{array}$ \\
\hline \multicolumn{5}{|c|}{$A P O B$ gene } \\
\hline rs1042031 & $\mathrm{C}>\mathrm{T}$ & 21225753 & Glu4181Lys & $\begin{array}{l}\text { F: caatcagatgcttgactttcatatggaatt } \\
\text { R: ttgagtaactcgtaccaagccatcaaacac }\end{array}$ \\
\hline rs6725189 & $\mathrm{G}>\mathrm{T}$ & 21219001 & Not announced & $\begin{array}{l}\text { F: ttcccagcctcagctcaacagagctatggg } \\
\text { R: cagcagtcggccctctctattgttctttcc }\end{array}$ \\
\hline \multicolumn{5}{|c|}{$A P O E$ gene } \\
\hline rs7412 & $\mathrm{C}>\mathrm{T}$ & 45412079 & Arg176Cys & $\begin{array}{l}\text { F: ctcctccgcgatgccgatgacctgcagaag } \\
\text { R: gcctggcagtgtaccaggccggggeccgcg }\end{array}$ \\
\hline rs429358 & $\mathrm{T}>\mathrm{C}$ & 45411941 & Cys130Arg & $\begin{array}{l}\text { F: gccogetgggcgcggacatggaggacgtg } \\
\text { R: gcggccgectggtgcagtaccgcggcgagg }\end{array}$ \\
\hline
\end{tabular}


Table 5. Cont.

\begin{tabular}{|c|c|c|c|c|}
\hline $\begin{array}{l}\text { Single Nucleotide } \\
\text { Polymorphism }\end{array}$ & $\begin{array}{l}\text { Nucleotide } \\
\text { Substitution }\end{array}$ & $\begin{array}{l}\text { Chromosomal } \\
\text { Position }\end{array}$ & $\begin{array}{l}\text { Amino Acid } \\
\text { Substitution }\end{array}$ & $\begin{array}{c}\text { Forward } 5^{\prime}-3^{\prime} \text { and } \\
\text { Reverse } 3^{\prime}-5^{\prime} \text { Polymerase } \\
\text { Chain Reaction Primers }\end{array}$ \\
\hline \multicolumn{5}{|c|}{ LIPC gene } \\
\hline rs1800588 & $\mathrm{C}>\mathrm{T}$ & 58723675 & $5^{\prime}$-upstream & $\begin{array}{c}\text { F: tctttgcttcttcgtcagctccttttgaca } \\
\text { R: gggggtgaagggttttctgcaccacacttt }\end{array}$ \\
\hline \multicolumn{5}{|c|}{ LPA gene } \\
\hline rs10455872 & $A>G$ & 161010118 & intronic & $\begin{array}{l}\text { F: tcagacaccttgttctcagaaccca } \\
\text { R: tgtgtttatacaggttagaggagaa }\end{array}$ \\
\hline \multicolumn{5}{|c|}{ NOTCH1 gene } \\
\hline rs13290979 & $A>G$ & 139425634 & intronic & $\begin{array}{l}\text { F: ccagcccagcagtgaagaaactgagcccac } \\
\text { R: accctcctggcctgacctacactcgggctt }\end{array}$ \\
\hline \multicolumn{5}{|c|}{$V D R$ gene } \\
\hline rs731236 & $A>G$ & 48238757 & Ile352Ile & $\begin{array}{l}\text { F: tgtgttggacaggcggtcctggatggcctc } \\
\text { R: atcagcgcggcgtcctgcaccccaggacga }\end{array}$ \\
\hline rs2228570 & $A>G$ & 48272895 & Met1Thr/Lys/Arg & $\begin{array}{l}\text { F: ggcagggaagtgctggccgccattgcctcc } \\
\text { R: tccctgtaagaacagcaagcaggccacggt }\end{array}$ \\
\hline \multicolumn{5}{|c|}{ CASR gene } \\
\hline rs1042636 & $A>G$ & 122003769 & Arg990Gly & $\begin{array}{l}\text { F: gatgagcctcagaagaacgccatggcccac } \\
\text { R: ggaattctacgcaccagaactccetggagg }\end{array}$ \\
\hline \multicolumn{5}{|c|}{ OPG gene } \\
\hline rs3134069 & $\mathrm{A}>\mathrm{C}$ & 119964988 & $5^{\prime}$-upstream & $\begin{array}{l}\text { F: ggagcttcctacgcgctgaacttctggagt } \\
\text { R: gcctcctcgaggtctttccactagcctcaa }\end{array}$ \\
\hline rs2073618 & $\mathrm{G}>\mathrm{C}$ & 119964052 & Asn3Lys & $\begin{array}{l}\text { F: gggacttaccacgagcgcgcagcacagcaa } \\
\text { R: ttgttcattgtggtcccoggaaacctcagg }\end{array}$ \\
\hline rs3102735 & $\mathrm{T}>\mathrm{C}$ & 119965070 & $5^{\prime}$-upstream & $\begin{array}{l}\text { F: ctttgctctagggttcgctgtctcccccat } \\
\text { R: aattccctggtctagaagttagacttgatg }\end{array}$ \\
\hline \multicolumn{5}{|c|}{$C A L C R$ gene } \\
\hline rs1801197 & $A>G$ & 93055753 & Leu481Pro & $\begin{array}{l}\text { F: tcgccttggttgttggctggttcattcctc } \\
\text { R: gctcctgatggcagatgtaaattgggatgt }\end{array}$ \\
\hline \multicolumn{5}{|c|}{ F2 gene } \\
\hline rs1799963 & $\mathrm{G}>\mathrm{A}$ & 46761055 & $3^{\prime}$-UTR & $\begin{array}{l}\text { F: gttcccaataaaagtgactctcagc } \\
\text { R: agcctcaatgctcccagtgctattc }\end{array}$ \\
\hline \multicolumn{5}{|c|}{ F5 gene } \\
\hline rs6025 & $\mathrm{T}>\mathrm{C}$ & 169519049 & Gln534Arg & $\begin{array}{l}\text { F: ttacttcaaggacaaaatacctgtattcct } \\
\text { R: gcctgtccagggatctgctcttacagatta }\end{array}$ \\
\hline rs6027 & $\mathrm{T}>\mathrm{C}$ & 169483561 & Asp2222Gly & $\begin{array}{l}\text { F: gggtttttgaatgttcaattctagtaaata } \\
\text { R: cacagccaaagagttccaggcgaagtgcaa }\end{array}$ \\
\hline \multicolumn{5}{|c|}{ F7 gene } \\
\hline rs6046 & $\mathrm{G}>\mathrm{A}$ & 113773159 & Arg412Gln/Pro/Leu & $\begin{array}{l}\text { F: acagtggaggcccacatgccacccactacc } \\
\text { R: gggcacgtggtacctgacgggcatcgtcag }\end{array}$ \\
\hline \multicolumn{5}{|c|}{ F13A1 gene } \\
\hline rs5985 & $\mathrm{C}>\mathrm{A}$ & 6318795 & Val35Leu & $\begin{array}{l}\text { F: taccttgcaggttgacgccccggggcacca } \\
\text { R: gccetgaagctccactgtgggcaggtcatc }\end{array}$ \\
\hline \multicolumn{5}{|c|}{ ITGB3 gene } \\
\hline rs5918 & $\mathrm{T}>\mathrm{C}$ & 45360730 & Leu59Pro & $\begin{array}{l}\text { F: tttgggctcctgacttacaggccetgcctc } \\
\text { R: gggctcacctcgctgtgacctgaaggagaa }\end{array}$ \\
\hline
\end{tabular}




\subsection{Statistical Analysis}

The statistical analysis was performed as in [22-24] using the SNPStats software [25]. To further define independent predictors of severe bioprosthetic mitral valve calcification, we carried out stepwise logistic regression with the plotting of the ROC curve and area under the curve.

Acknowledgments: There was no financial assistance with the project.

Author Contributions: Anastasia V. Ponasenko, Maria V. Khutornaya, Anton G. Kutikhin and Leonid S. Barbarash conceived and designed the study; Natalia V. Rutkovskaya and Natalia V. Kondyukova collected the patient data; Anna V. Tsepokina and Maria V. Khutornaya collected the blood specimens, isolated DNA and performed genotyping; Anton G. Kutikhin carried out statistical analysis; Anastasia V. Ponasenko, Maria V. Khutornaya, Anton G. Kutikhin and Arseniy E. Yuzhalin wrote the manuscript.

Conflicts of Interest: The authors declare no conflict of interest.

\section{References}

1. Nishimura, R.A.; Otto, C.M.; Bonow, R.O.; Carabello, B.A.; Erwin, J.P., 3rd; Guyton, R.A.; O'Gara, P.T.; Ruiz, C.E.; Skubas, N.J.; Sorajja, P.; et al. 2014 AHA/ACC guideline for the management of patients with valvular heart disease: A report of the American College of Cardiology/American Heart Association Task Force on Practice Guidelines. J. Am. Coll. Cardiol. 2014, 63, 57-185. [CrossRef] [PubMed]

2. Roberts, W.C. The senile cardiac calcification syndrome. Am. J. Cardiol. 1986, 58, 572-574. [CrossRef]

3. Eric Jamieson, W.R.; Marchand, M.A.; Pelletier, C.L.; Norton, R.; Pellerin, M.; Dubiel, T.W.; Aupart, M.R.; Daenen, W.J.; Holden, M.P.; David, T.E.; et al. Structural valve deterioration in mitral replacement surgery: Comparison of Carpentier-Edwards supra-annular porcine and perimount pericardial bioprostheses. J. Thorac. Cardiovasc. Surg. 1999, 118, 297-304. [CrossRef]

4. Jamieson, W.R.; Riess, F.C.; Raudkivi, P.J.; Metras, J.; Busse, E.F.; Goldstein, J.; Fradet, G.J. Medtronic Mosaic porcine bioprosthesis: Assessment of 12-year performance. J. Thorac. Cardiovasc. Surg. 2011, 142, $302-307$. [CrossRef] [PubMed]

5. Barbarash, O.; Rutkovskaya, N.; Hryachkova, O.; Gruzdeva, O.; Uchasova, E.; Ponasenko, A.; Kondyukova, N.; Odarenko, Y.; Barbarash, L. Impact of recipient-related factors on structural dysfunction of xenoaortic bioprosthetic heart valves. Patient Pref. Adherence 2015, 9, 389-399.

6. Bella, J.N.; Tang, W.; Kraja, A.; Rao, D.C.; Hunt, S.C.; Miller, M.B.; Palmieri, V.; Roman, M.J.; Kitzman, D.W.; Oberman, A.; et al. Genome-wide linkage mapping for valve calcification susceptibility loci in hypertensive sibships: The Hypertension Genetic Epidemiology Network Study. Hypertension 2007, 49, 453-460. [CrossRef] [PubMed]

7. Kutikhin, A.G.; Yuzhalin, A.E.; Brusina, E.B.; Ponasenko, A.V.; Golovkin, A.S.; Barbarash, O.L. Genetic predisposition to calcific aortic stenosis and mitral annular calcification. Mol. Biol. Rep. 2014, 41, 5645-5663. [CrossRef] [PubMed]

8. Yuzhalin, A.E.; Kutikhin, A.G. Integrative systems of genomic risk markers for cancer and other diseases: Future of predictive medicine. Cancer Manag. Res. 2012, 4, 131-135. [CrossRef] [PubMed]

9. Bakhtiar, S.M.; Ali, A.; Baig, S.M.; Barh, D.; Miyoshi, A.; Azevedo, V. Identifying human disease genes: Advances in molecular genetics and computational approaches. Genet. Mol. Res. 2014, 13, 5073-5087. [CrossRef] [PubMed]

10. Novaro, G.M.; Sachar, R.; Pearce, G.L.; Sprecher, D.L.; Griffin, B.P. Association between apolipoprotein E alleles and calcific valvular heart disease. Circulation 2003, 108, 1804-1808. [CrossRef] [PubMed]

11. Tangri, N.; Alam, A.; Wooten, E.C.; Huggins, G.S. Lack of association of Klotho gene variants with valvular and vascular calcification in Caucasians: A candidate gene study of the Framingham Offspring Cohort. Nephrol. Dial. Transplant. 2011, 26, 3998-4002. [CrossRef] [PubMed]

12. Davutoglu, V.; Nacak, M. Influence of angiotensin-converting enzyme gene insertion/deletion polymorphism on rheumatic valve involvement, valve severity and subsequent valve calcification. J. Heart Valve Dis. 2005, 14, 277-281. [PubMed]

13. Thanassoulis, G.; Campbell, C.Y.; Owens, D.S.; Smith, J.G.; Smith, A.V.; Peloso, G.M.; Kerr, K.F.; Pechlivanis, S.; Budoff, M.J.; Harris, T.B.; et al. Genetic associations with valvular calcification and aortic stenosis. N. Engl. J. Med. 2013, 368, 503-512. [CrossRef] [PubMed] 
14. Ponasenko, A.V.; Khutornaya, M.V.; Kutikhin, A.G.; Yuzhalin, A.E.; Hryachkova, O.N.; Golovkin, A.S. Toll-like receptor 2 gene polymorphism is associated with risk of mitral valve disease. Med. Kuzbasse 2015, 14, 24-32.

15. Davutoglu, V.; Celik, A.; Aksoy, M. Contribution of selected serum inflammatory mediators to the progression of chronic rheumatic valve disease, subsequent valve calcification and NYHA functional class. J. Heart Valve Dis. 2005, 14, 251-256. [PubMed]

16. Elmariah, S.; Budoff, M.J.; Delaney, J.A.; Hamirani, Y.; Eng, J.; Fuster, V.; Kronmal, R.A.; Halperin, J.L.; O'Brien, K.D. Risk factors associated with the incidence and progression of mitral annulus calcification: The multi-ethnic study of atherosclerosis. Am. Heart J. 2013, 166, 904-912. [CrossRef] [PubMed]

17. Bre, L.P.; McCarthy, R.; Wang, W. Prevention of bioprosthetic heart valve calcification: Strategies and outcomes. Curr. Med. Chem. 2014, 21, 2553-2556. [CrossRef] [PubMed]

18. American College of Cardiology; American Heart Association Task Force on Practice Guidelines (Writing Committee to revise the 1998 guidelines for the management of patients with valvular heart disease); Society of Cardiovascular Anesthesiologists; Bonow, R.O.; Carabello, B.A.; Chatterjee, K.; de Leon, A.C., Jr.; Faxon, D.P.; Freed, M.D.; Gaasch, W.H.; et al. ACC/AHA 2006 guidelines for the management of patients with valvular heart disease: A report of the American College of Cardiology/American Heart Association Task Force on Practice Guidelines (writing Committee to Revise the 1998 guidelines for the management of patients with valvular heart disease) developed in collaboration with the Society of Cardiovascular Anesthesiologists endorsed by the Society for Cardiovascular Angiography and Interventions and the Society of Thoracic Surgeons. J. Am. Coll. Cardiol. 2006, 48, 1-148.

19. Astapov, D.A.; Karas'kov, A.M.; Semenova, E.I.; Demidov, D.P. The mithral valve replacement with biological prostheses: Early and long-term results. Khirurgiia 2013, 9, 18-23. [PubMed]

20. Xu, Z.; Taylor, J.A. SNPinfo: Integrating GWAS and candidate gene information into functional SNP selection for genetic association studies. Nucleic Acids Res. 2009, 37, 600-605. [CrossRef] [PubMed]

21. Dayem Ullah, A.Z.; Lemoine, N.R.; Chelala, C. SNPnexus: A web server for functional annotation of novel and publicly known genetic variants (2012 update). Nucleic Acids Res. 2012, 40, 65-70. [CrossRef] [PubMed]

22. Golovkin, A.S.; Ponasenko, A.V.; Khutornaya, M.V.; Kutikhin, A.G.; Salakhov, R.R.; Yuzhalin, A.E.; Zhidkova, I.I.; Barbarash, O.L.; Barbarash, L.S. Association of TLR and TREM-1 gene polymorphisms with risk of coronary artery disease in a Russian population. Gene 2014, 550, 101-109. [CrossRef] [PubMed]

23. Golovkin, A.S.; Ponasenko, A.V.; Yuzhalin, A.E.; Salakhov, R.R.; Khutornaya, M.V.; Kutikhin, A.G.; Rutkovskaya, N.V.; Savostyanova, Y.Y.; Barbarash, L.S. An association between single nucleotide polymorphisms within TLR and TREM-1 genes and infective endocarditis. Cytokine 2015, 71, 16-21. [CrossRef] [PubMed]

24. Kutikhin, A.G.; Ponasenko, A.V.; Khutornaya, M.V.; Yuzhalin, A.E.; Zhidkova, I.I.; Salakhov, R.R.; Golovkin, A.S.; Barbarash, O.L.; Barbarash, L.S. Association of TLR and TREM-1 gene polymorphisms with atherosclerosis severity in a Russian population. Meta Gene 2016, 9, 76-89. [CrossRef] [PubMed]

25. Solé, X.; Guinó, E.; Valls, J.; Iniesta, R.; Moreno, V. SNPStats: A web tool for the analysis of association studies. Bioinformatics 2006, 22, 1928-1929. [CrossRef] [PubMed]

(C) 2016 by the authors; licensee MDPI, Basel, Switzerland. This article is an open access article distributed under the terms and conditions of the Creative Commons Attribution (CC-BY) license (http:/ / creativecommons.org/licenses/by/4.0/). 